Reviu Akuntansi dan Bisnis Indonesia, Vol. 2 No. 1, Hlm: 64-74, Juli 2018

Website: http://journal.umy.ac.id/index.php/rab

\title{
Peran Mekanisme Corporate Governance Terhadap Tingkat Kepatuhan Mandatory Disclosure Konvergensi IFRS Dan Dampaknya Terhadap Return Saham : Studi Empiris pada Perusahaan BUMN yang terdaftar di Bursa Efek Indonesia tahun 2014 - 2017
}

\author{
Dianing Widya Kusumastuti; Evi Rahmawati \\ Program Studi Akuntansi Universitas Muhammadiyah Yogyakarta \\ I N F O A R T IKEL

\section{Kata Kunci:} \\ ReturnSaham, Mandatory \\ Disclosure, Kepemilikan \\ Manajerial, Kepemilikan \\ Institusional, Kepemilikan \\ Asing, Jumlah Anggota \\ Dewan Komisaris, Proporsi \\ Komisaris Independen, \\ Jumlah Rapat Dewan \\ Komisaris dan Jumlah \\ Anggota Komite Audit. \\ Jenis Artikel: \\ Penelitian Empiris \\ Correspondence: \\ Evirahmawati@gmail.com

\begin{abstract}
A B S T R A K
\end{abstract} \\ Penelitian ini bertujuan untuk menganalisis peran mekanisme corporate \\ governance terhadap tingkat kepatuhan mandatory disclosure konvergensi \\ IFRS serta dampaknya terhadap return sahampada perusahaan BUMN \\ yang terdaftar di Bursa Efek Indonesia tahun 2014-2017. Dalam penelitian \\ ini diperoleh 80 sampel yang dipilih dengan metode purposive sampling. \\ Metode analisis pada penelitian ini menggunakan regresi berganda dan \\ sederhana dengan program IBM SPSS versi 21. Hasil penelitian ini \\ menunjukkan bahwa kepemilikan asing, jumlah anggota dewan komisaris, \\ jumlah rapat dewan komisaris dan jumlah anggota komite audit \\ berpengaruh terhadap tingkat kepatuhan mandatory disclosure \\ konvergensi IFRS. Untuk kepemilikan manajerial, kepemilikan \\ institusional dan proporsi komisaris independen tidak berpengaruh \\ terhadap tingkat kepatuhan mandatory disclosurekonvergensi IFRS. \\ Sedangkan tingkat kepatuhan mandatory disclosure konvergensi IFRS \\ tidak berpengaruh terhadap return saham.
}

(C) 2019 RAB. Published by Universitas Muhammadiyah Yogyakarta

\section{PENDAHULUAN}

Pelaporan keuangan suatu perusahaan diwujudkan dalam bentuk laporan keuangan yang diterbitkan oleh perusahaan dalam kurun waktu tertentu. Laporan keuangan memuat informasi yang dijadikan sebagai bahan pertimbangan bagi stakeholders untuk membuat keputusan yang tepat. Misalnya, keputusan investasi oleh investor dan calon investor.

Semakin bertambahnya kebutuhan informasi bagi investor dan stakeholders lainnya, membuat perusahaan perlu untuk mengungkapkan lebih banyak informasi dalam laporan keuangan. Investor menginginkan informasi yang luas dan relevan untuk mengambil keputusan dengan tepat yang berkaitan dengan investasi modalnya pada suatu perusahaan.

Terdapat dua jenis pengungkapan, yaitu mandatory disclosure dan voluntary disclosure. Mandatory disclosure lebih kepada pengungkapan informasi yang harus dilakukan perusahaan karena dianggap perlu/penting bagi pemakainya (Suhardjanto dan Miranti, 2009). Mandatory disclosure sangat penting untuk dilakukan, karena semakin luas pengungkapan informasi yang disajikan dalam annual report maka kualitas perusahaan akan semakin baik. Mandatory disclosure 
juga menjadi sarana bagi perusahaan untuk memberikan jaminan bahwa modal yang ditanamkan investor pada perusahaan telah dikelola dengan efektif (Istiningrum, 2016).

Indonesia telah melakukan konvergensi standar akuntansi internasional, yaitu IFRS pada 1 Januari 2012. IFRS juga telah diadopsi oleh negara-negara lain, sehingga hal ini memudahkan penggunaan informasi laporan keuangan bagi investor asing yang ingin menanamkan modalnya pada perusahaan di Indonesia. IFRS juga menekankan kaitannya kepatuhan wajib yang harus dilakukan secara penuh oleh perusahaan.

Pada kenyataannya, pasca pengadopsian IFRS di Indonesia, tingkat keputahan dalam pengungkapan wajib belum mencapai $100 \%$. Oleh karena itu diperlukan CG (corporate governance) yang berperan untuk mengawasi manajemen dalam pengelolaan perusahaan serta memastikan bahwa perusahaan telah melakukan pengungkapan informasi yang dibutuhkan pengguna informasi.

Dengan adanya struktur dalam CG diharapkan dapat meminimalisir asimetri informasi. Transparansi merupakan salah satu prinsip dalam CG. Transparansi dapat diwujudkan dalam pengungkapan informasi yang dilakukan perusahaan. Artinya, perusahaan tidak hanya mengungkapkan informasi yang baik-baik saja, namun perusahaan juga harus menyampaikan informasi sesuai apa yang terjadi tanpa ada yang dimanipulasi atau disembunyikan.

Struktur kepemilikan juga merupakan bagian dari mekanisme CG. Penelitian Fauziah (2015) mengidentifikasi bahwa mekanisme CG yang diproksikan dalam kepemilikan manajerial berpengaruh positif terhadap tingkat keputahan mandatory disclosure konvergensi IFRS. Kepemilikan institusional dapat meningkatkan kepatuhan perusahaan dalam melakukan mandatory disclosure konvergensi IFRS, hal ini sejalan dengan hasil penelitian Fauziah (2015). Dengan adanya keterbatasan geografis dan bahasa, perusahaan yang memiliki kepemilikan asing akan melakukan pengungkapan informasi yang luas, hal ini sejalan dengan penelitian yang dilakukan Alvionita dan Taqwa (2015).

Selain itu, mekanisme GC juga diproksikan dalam jumlah anggota dewan komisaris. Berdasarkan penelitian Gunawan dan Hendrawati (2016) menunjukkan bahwa jumlah anggota dewan komisaris berpengaruh positif terhadap tingkat kepatuhan mandatory disclosure. Keberadaan komisaris independen dianggap mampu mempengaruhi kepatuhan perusahaan dalam melakukan pengungkapan wajib, hal ini sejalan dengan hasil penelitian Fauziah (2015).

Selaku pihak yang mengawasi manajemen perusahaan, kualitas kinerja dari dewan komisaris dapat dilihat dari frekuensi rapat yang mereka lakukan. Berdasarkan penelitian yang dilakukan Sutiyok dan Rahmawati (2014) menunjukkan bahwa jumlah rapat dewan komisaris berpengaruh positif terhadap tingkat kepatuhan mandatory disclosure. Komite audit memiliki peran untuk membantu tugas dewan komisaris. Keberadaan komite audit dianggap dapat meningkatkan kepatuhan pengungkapan wajib perusahaan, hal ini sejalan dengan hasil penelitian yang dilakukan Gunawan dan Hendrawati (2016).

Menurut Ahmad, dkk. (2017) menyebutkan bahwa pengungkapan informasi akan mempengaruhi tingkat kepercayaan investor terhadap perusahaan. Investor memerlukan informasi yang relevan dan akurat sebagai bahan pertimbangan pengambilan keputusan. Apabila keputusan yang diambil investor tepat, maka akan mempengaruhi tingkat pengembalian (return saham) yang investor terima.

\section{TINJAUAN LITERATUR DAN PERUMUSAN HIPOTESIS}

\section{Teori Keagenan}

Teori agensi merupakan teori yang menjelaskan tentang hubungan antara pihak pemilik dan manajemen. Teori keagenan sebagai hubungan kerjasama antara pemilik dan manajemen. Dalam hubungan antara pemilik dan manajemen terdapat asimetri informasi, yang mana pihak manajemen lebih mengetahui informasi tentang internal perusahaan dan bagaimana prospek perusahaan di masa depan. Sehingga diperlukan CG untuk meminimalisir asimetri informasi tersebut. 


\section{Teori Stakeholders}

Menurut Gunawan dan Hendrawati (2015), teori stakeholders menyatakan bahwa perusahaan bukanlah entitas yang hanya beroperasi untuk kepentingan sendiri, namun harus mampu memberikan manfaat bagi stakeholders-nya. Salah satu manfaat yang dapat diberikan kepada stakeholders yaitu dengan melakukan pengungkapan informasi secara luas.

\section{Teori Persinyalan}

Teori persinyalan dapat menjelaskan bahwa asimetri informasi dapat dikurangi dengan memberikan sinyal kepada pihak terkait. Teori ini menggambarkan bagaimana perusahaan dapat memberikan sinyal kepada penerima sinyal (signaler). Sinyal dapat berupa pengungkapan informasi perusahaan. Dengan pengungkapan informasi, pengguna informasi nantinya akan menunjukkan reaksi berupa pengambilan keputusan.

\section{Penurunan Hipotesis}

\section{Pengaruh Kepemilikan Manajerial terhadap Tingkat Kepatuhan Mandatory Disclosure Konvergensi IFRS}

Kepemilikan manajerial adalah proporsi kepemilikan saham perusahaan yang dimiliki oleh pihak manajemen (dewan direksi dan dewan komisaris). Fauziah (2015) meneliti tentang pengaruh kepemilikan manajerial terhadap tingkat kepatuhan mandatory disclosure pasca konvergensi IFRS dengan hasil berpengaruh signifikan positif. Manajemen memiliki sedikit motivasi untuk bertindak sesuai keinginan pemegang saham, sehingga diperlukan kepemilikan manajerial untuk memotivasi manjemen agar meningkatkan kinerjanya. Kepemilikan manajerial artinya pihak manajemen tidak hanya berperan sebagai pengelola perusahaan, namun mereka dapat andil dalam pengambilan keputusan. Dengan kepemilikan saham yang besar dalam perusahaan, maka manajemen akan memiliki motivasi yang tinggi dalam mematuhi peraturan yang ada, termasuk ketaatan dalam melakukan pengungkapan wajib. Dari uraian tersebut, peneliti mengajukan hipotesis sebagai berikut:

\section{$\boldsymbol{H}_{\boldsymbol{I}}$ : Kepemilikan manajerial berpengaruh positif terhadap tingkat kepatuhan mandatory disclosure konvergensi IFRS.}

\section{Pengaruh Kepemilikan Institusi terhadap Tingkat Mandatory Disclosure Konvergensi IFRS.}

Kepemilikan institusional adalah proporsi kepemilikan saham suatu perusahaan oleh lembaga non-bank seperti yayasan, reksadana, asuransi, dana pensiun dan institusi lainnya. Dari penelitian Widjayanti dan Wahidawati (2015) didapatkan hasil bahwa kepemilikan institusional berpengaruh terhadap tingkat kepatuhan mandatory disclosure konvergensi IFRS. Semakin tinggi kepemilikan institusional maka usaha pengawasan akan dilakukan dengan ketat terhadap manajemen sehingga akan menghalangi sifat opportunistik para manajer. Tingginya kepemilikan institusional akan menekan manajemen agar mengungkapkan informasi yang investor inginkan. Dari uraian tersebut, peneliti mengajukan hipotesis sebagai berikut :

\section{$\boldsymbol{H}_{2}$ : Kepemilikan Institusional berpengaruh positif terhadap tingkat kepatuhan mandatory} disclosure konvergensi IFRS. 


\section{Pengaruh Kepemilikan Asing terhadap Tingkat Mandatory Disclosure Konvergensi IFRS.}

Kepemilikan asing adalah proporsi kepemilikan saham suatu perusahaan yang dimiliki oleh individu maupun institusi yang berada di luar negeri. Penelitian Rustiarini (2011) menunjukkan bahwa kepemilikan asing berpengaruh terhadap pengungkapan CSR. Dengan semakin tingginya kepemilikan asing akan menjadikan proses monitoring perusahaan dapat dilakukan dengan baik, sehingga manajemen akan memberikan informasi menyeluruh bagi pihak-pihak yang membutuhkan informasi. Dari uraian tersebut peneliti mengajukan hipotesis sebagai berikut :

\section{$\boldsymbol{H}_{3} \quad$ : Kepemilikan asing berpengaruh positif terhadap tingkat kepatuhan mandatory disclosure konvergensi IFRS.}

\section{Jumlah Anggota Dewan Komisaris terhadap Tingkat Kepatuhan Mandatory Disclosure Konvergensi IFRS}

Anggota dewan komisaris memiliki peran melakukan pengawasan dan pemberian nasehat kepada direksi serta memastikan bahwa perusahaan telah mengimplementasikan corporate governance dengan baik (Hikmah dkk., 2011). Dari penelitian yang dilakukan oleh Gunawan dan Hendrawati (2016), terdapat pengaruh signifikan positif jumlah anggota dewan komisaris terhadap tingkat kepatuhan mandatory disclosure konvergensi IFRS. Semakin besar dewan komisaris disuatu perusahaan akan meningkatkan pengawasan, pengevaluasian, dan pelaksanaan kebijakan direksi yang semakin berkualitas sesuai dengan tujuan perusahaan, serta semakin berfungsinya corporate governance dalam meningkatkan kepatuhan mandatory disclosure konvergensi IFRS. Dari uraian tersebut peneliti mengajukan hipotesis sebagai berikut :

$\boldsymbol{H}_{4}$ : Jumlah anggota dewan komisaris berpengaruh positif terhadap tingkat kepatuhan mandatory disclosure konvergensi IFRS.

\section{Proporsi Komisaris Independen terhadap Tingkat Kepatuhan Mandatory Disclosure Konvergensi IFRS}

Dewan komisaris independen merupakan anggota dewan komisaris yang bukan berasal dari dalam perusahaan. Komisaris independen dapat memastikan apakah ketransparanan telah tercipta, struktur organisasi sudah baik, serta keputusan yang diambil bersifat rasional (Utami dkk., 2012).

Berdasarkan hasil penelitian yang dilakukan Widjayanti dan Wahidawati (2015), terdapat pengaruh signifikan positif antara proporsi komisaris independen berpengaruh pada tingkat kepatuhan mandatory disclosure konvergensi IFRS. Menurut Widjayanti dan Wahidawati (2015) menyebutkan bahwa semakin besar komposisi komisaris independen maka kualitas pengawasan yang dilakukan dewan komisaris akan semakin bagus karena semakin banyak pihak yang independen maka transparansi dalam melakukan pelaporan akan semakin baik. Dari uraian tersebut peneliti mengajukan hipotesis sebagai berikut:

$\mathrm{H}_{5}$ : Proporsi komisaris independen berpengaruh positif terhadap tingkat kepatuhan mandatory disclosure konvergensi IFRS.

Pengaruh Jumlah Rapat Dewan Komisaris terhadap Tingkat Kepatuhan Mandatory Disclosure Konvergensi IFRS 
Kualitas kinerja dari dewan komisaris tidak hanya dilihat dari jumlah atau proporsinya saja. Namun, jumlah rapat yang dilakukan juga akan mempengaruhi kualitas kerjanya dalam melakukan pengendalian dan pengawasan terhadap manajemen.

Hasil penelitian Kharis dan Suhardjanto (2012) menunjukkan bahwa jumlah rapat dewan komisaris berpengaruh positif terhadap kepatuhan pengungkapan wajib. Semakin sering dewan komisaris melakukan rapat maka pengawasan terhadap manajemen akan lebih optimal. Dewan komisaris akan memastikan apakah tata kelola perusahaan telah dilaksanakan dengan baik, jika sudah maka tingkat kepatuhan pengungkapan wajib akan semakin tinggi. Artinya, perusahaan akan melakukan pengungkapan informasi secara lengkap. Dari uraian tersebut peneliti mengajukan hipotesis sebagai berikut:

$\boldsymbol{H}_{6}$ : Jumlah rapat dewan komisaris berpengaruh terhadap tingkat kepatuhan mandatory disclosure konvergensi IFRS

\section{Pengaruh Jumlah Komite Audit terhadap Tingkat Kepatuhan Mandatory Disclosure Konvergensi IFRS}

Komite audit bertanggung jawab langsung kepada dewan komisaris. Komite audit berperan untuk mengawasi pengendalian internal perusahaan dan pelaporan keuangannya. Selain itu, komite audit juga berperan untuk mengawasi dan menjembatani hubungan antara auditor internal dan eksternal (Rahayuni dkk., 2018).

Hasil penelitian yang dilakukan Pitasari dan Septiani (2014) menunjukkan bahwa jumlah anggota komite audit berpengaruh signifikan positif terhadap tingkat kepatuhan pengungkapan konvergensi IFRS. Pada penelitian Pitasari dan Septiani (2014), jumlah anggota komite audit pada perusahaan sampel telah memenuhi syarat minimum yaitu tiga orang, yang mana komite audit akan memberikan pendapat profesionalnya terhadap dewan komisaris dan komite audit juga bertanggung jawab untuk memastikan bahwa perusahaan telah melakukan pengungkapan informasi sesuai dengan peraturan. Dari uraian tersebut peneliti mengajukan hipotesis sebagai berikut :

$H_{7} \quad$ :Jumlah anggota komite audit berpengaruh positif terhadap tingkat kepatuhan mandatory disclosure konvergensi IFRS.

\section{Tingkat Kepatuhan Mandatory Disclosure Konvergensi IFRS terhadap Return Saham}

Return saham merupakan salah satu motivasi mengapa investor melakukan penanaman modal pada suatu perusahaan. Penelitian Budi dan Djazuli (2012) menunjukkan bahwa pengungkapan informasi tentang CSR (Corporate Social Responsibility) dapat meningkatkan return saham. Dengan diumumkannya informasi akuntansi maka akan memberikan sinyal kepada investor untuk melakukan keputusan investasi. Jika informasi yang diumumkan tersebut positif, maka investor akan tertarik untuk melakukan perdagangan saham. Semakin banyak perdagangan saham yang dilakukan investor, maka akan mendorong naiknya harga saham sehingga return yang didapat investor akan meningkat. Dari uraian tersebut peneliti mengajukan hipotesis sebagai berikut:

$\boldsymbol{H}_{s} \quad$ : Tingkat kepatuhan mandatory disclosure konvergensi IFRS berpengaruh terhadap return saham. 


\section{METODE PENELITIAN}

Sampel dalam penelitian ini menggunakan laporan keuangan tahunan dari perusahaan BUMN yang terdaftar di Bursa Efek Indonesia tahun 2014-2017. Jenis data pada penelitian ini adalah data sekunder berupa annual report yang didapat dari Kantor Perwakilan Bursa Efek Indonesia di Yogyakarta. Untuk mendapatkan sampel yang representatif, peneliti menggunakan metode purposive sampling dengan kriteria sebagai berikut:

1. Peusahaan BUMN yang terdaftar di BEI secara berturut-turut pada tahun 2014, 2015, 2016 dan 2017.

2. Mempublikasikan informasi yang dibutuhkan peneliti.

Data dalam penelitian ini diperoleh dari data sekunder, kemudian dilanjutkan dengan analisis, penghitungan dan percatatan. Peneliti menggunakan data dari annual report perusahaan BUMN.

\section{HASIL DAN PEMBAHASAN}

Tabel 1 Proses Pengambilan Sampel

\begin{tabular}{lccccc}
\hline \multicolumn{1}{c}{ Keterangan } & Tahun & Tahun & Tahun & Tahun & \multirow{2}{*}{ Total } \\
& 2014 & 2015 & 2016 & 2017 & \\
\hline $\begin{array}{l}\text { Perusahaan BUMN yang terdaftar } \\
\text { di Bursa Efek Indonesia }\end{array}$ & 20 & 20 & 20 & 20 & 80 \\
Jumlah sampel yang dapat diolah & 20 & 20 & 20 & 20 & 80 \\
\hline
\end{tabular}

\section{A. Analisis Deskriptif}

Tabel 2 Statistik Deskriptif

\begin{tabular}{lccccc}
\hline & $\mathrm{N}$ & Minimum & Maximum & Mean & Std. Deviation \\
\hline KPM & 80 & 0 & .47 & .03 & .08 \\
KPI & 80 & 3.81 & 35.29 & 13.64 & 7.66 \\
KPA & 80 & 1 & 42 & 16.64 & 12.75 \\
JADK & 80 & 3 & 11 & 6 & 1.36 \\
PKI & 80 & .20 & .64 & .40 & .10 \\
JRDK & 80 & 12 & 87 & 30 & 13.77 \\
JAKA & 80 & 2 & 7 & 4 & 1.20 \\
MD & 80 & 72.50 & 94.59 & 83.26 & 5.35 \\
RS & 80 & -.78 & 8.31 & .26 & 1.30 \\
\hline
\end{tabular}

\section{B. Uji Hipotesis}

Tabel Hasil Uji $t$, Model Penelitian 1

\begin{tabular}{|c|c|c|c|c|c|c|}
\hline & \multirow[t]{2}{*}{ Model } & \multicolumn{2}{|c|}{ Unstandardized Coefficients } & \multirow{2}{*}{$\begin{array}{c}\text { Standardized } \\
\text { Coefficients } \\
\text { Beta } \\
\end{array}$} & \multirow[t]{2}{*}{$t$} & \multirow{2}{*}{ Sig. } \\
\hline & & $\mathrm{B}$ & Std. Error & & & \\
\hline \multirow{8}{*}{1} & (Constant) & 3.996 & .063 & & 63.531 & .000 \\
\hline & KPM & -.088 & .068 & -.106 & -1.283 & .204 \\
\hline & KPI & .014 & .011 & .119 & 1.245 & .217 \\
\hline & KPA & .014 & .006 & .225 & 2.163 & .034 \\
\hline & JADK & .073 & .033 & .256 & 2.182 & .032 \\
\hline & PKI & -.030 & .026 & -.110 & -1.141 & .257 \\
\hline & JRDK & .039 & .016 & .245 & 2.371 & .020 \\
\hline & JAKA & .048 & .022 & .222 & 2.173 & .033 \\
\hline
\end{tabular}




\section{Pengujian Hipotesis Satu}

Variabel Kepemilikan Manajerial (KPM) memiliki tingkat signifikansi sebesar 0,204 > alpha $(0,05)$ dengan nilai koefisien regresi sebesar $-0,088$. Dengan demikian hipotesis satu $\left(\mathrm{H}_{1}\right)$ ditolak. Kepemilikan manajerial di perusahaan BUMN masih rendah, sehingga belum tercipta keselarasan kepentingan antara manajemen dengan investor. Hal tersebut diduga belum mampu mendorong pihak manajemen perusahaan untuk melakukan pengungkapan informasi yang memadai. Hasil penelitian ini sejalan dengan penelitian Alvionita dan Tawqa (2015) yang menyatakan bahwa kepemilikan manajerial tidak berpengaruh signifikan terhadap tingkat kepatuhan mandatory disclosure PSAK konvergensi IFRS.

\section{Pengujian Hipotesis Dua}

Variabel Kepemilikan Institusional (KPI) memiliki tingkat signifikansi sebesar 0,217 > alpha $(0,05)$ dengan nilai koefisien regresi sebesar 0,014. Dengan demikian hipotesis dua $\left(\mathrm{H}_{2}\right)$ ditolak. Kepemilikan institusional di perusahaan BUMN masih rendah sehingga belum mampu meningkatkan pengungkapan wajib yang dilakukan perusahaan. Hal tersebut diduga bahwa keberadaan pihak institusi belum mampu menekan pihak manajemen untuk melakukan pengungkapan wajib.

\section{Pengujian Hipotesis Tiga}

Variabel Kepemilikan Asing (KPA) memiliki tingkat signifikansi sebesar 0,034 < alpha $(0,05)$ dengan nilai koefisien regresi sebesar 0,014. Dengan demikian hipotesis tiga $\left(\mathrm{H}_{3}\right)$ diterima. Perusahaan dengan kepemilikan asing cenderung akan memperhatikan jumlah pengungkapan informasi dalam laporan keuangan karena keterbatasan geografis dan bahasa (Serly, 2017). Manurung (2006) menyebutkan bahwa perusahaan dengan kepemilikan asing akan cenderung melakukan pengungkapan informasi yang memadai, hal ini dikarenakan investor asing diklaim dapat meningkatkan efisiensi dan good corporate governance suatu perusahaan.

\section{Pengujian Hipotesis Empat}

Variabel Jumlah Anggota Dewan Komisaris (JADK) memiliki tingkat signifikansi sebesar $0,032<$ alpha $(0,05)$ dengan nilai koefisien regresi sebesar 0,073 . Dengan demikian hipotesis empat $\left(\mathrm{H}_{4}\right)$ diterima. Dengan semakin banyaknya anggota dewan komisaris dalam suatu perusahaan maka monitoring terhadap pihak manajemen akan semakin ketat sehingga akan mereduksi peluang para manajer untuk melakukan tindakan opportunistik pihak manajemen perusahaan yang cenderung mementingkan dirinya sendiri.

\section{Pengujian Hipotesis Lima}

Variabel Proporsi Komisaris Independen (KPI) memiliki tingkat signifikansi sebesar 0,257 $>$ alpha $(0,05)$ dengan nilai koefisien regresi sebesar -0,030. Dengan demikian hipotesis lima $\left(\mathrm{H}_{5}\right)$ ditolak. Keberadaan komisaris independen hanya dianggap sebagai penyeimbang saja dan mereka tidak memiliki kuasa penuh dalam pengambilan keputusan dewan komisaris (Meiflowerina, dkk., 2014). Hasil penelitian ini sejalan dengan penelitian yang dilakukan Gunawan dan Hendrawati (2016).

\section{Pengujian Hipotesis Enam}

Variabel Jumlah Rapat Dewan Komisaris (JRDK) memiliki tingkat signifikansi sebesar 0,020 $<$ alpha $(0,05)$ dengan nilai koefisien regresi sebesar 0,039. Dengan demikian hipotesis enam $\left(\mathrm{H}_{6}\right)$ diterima. Intensitas rapat dewan komisaris yang tinggi menunjukkan bahwa kebijakan perusahaan 
tidak diputuskan sendiri oleh pihak manajemen, melainkan pihak manajemen akan berkomunikasi dan berkoordinasi dengan dewan komisaris sebelum melakukan pengambilan keputusan terkait kebijakan perusahaan. Semakin sering diadakannya rapat, maka dewan komisaris semakin mudah dalam melakukan pengawasan terhadap pihak manajemen apakah mereka telah melakukan pengungkapan informasi yang memadai sebagai bentuk akuntabilitas dan transparansi perusahaan kepada pihak yang berkepentingan. Hasil penelitian ini mendukung penelitian yang dilakukan Suhardjanto (2012).

\section{Pengujian Hipotesis Tujuh}

Variabel Jumlah Anggota Komite Audit (JAKA) memiliki tingkat signifikansi sebesar 0,033 $<$ alpha $(0,05)$ dengan nilai koefisien regresi sebesar 0,048. Dengan demikian hipotesis tujuh $\left(\mathrm{H}_{7}\right)$ diterima. Komite audit dapat melakukan koordinasi dan kerjasama dengan anggotanya untuk melaksanakan fungsinya yaitu memberikan pendapat profesional kepada dewan komisaris dan mengawasi pelaporan keuangan perusahaan. Komite audit akan mereview apakah laporan keuangan yang disajikan perusahaan telah memadai atau tidak, termasuk memastikan apakah pengungkapan informasi telah dilaksanakan sesuai peraturan atau belum. Oleh karena itu, komite audit merupakan bagian penting dalam pelaksanaan corporate governance. Hasil penelitian ini mendukung penelitian yang dilakukan Gunawan dan Hendrawati (2016).

Tabel Hasil Uji $t$, Model Penelitian 2

\begin{tabular}{llccccc}
\hline \multirow{2}{*}{ Model } & \multicolumn{2}{c}{ Unstandardized Coefficients } & $\begin{array}{c}\text { Standardized } \\
\text { Coefficients } \\
\text { Beta }\end{array}$ & $t$ & Sig. \\
& & B & Std. Error & B & & \\
\hline \multirow{2}{*}{1} & (Constant) & 5.644 & 2.801 & & 2.015 & .047 \\
& MD & -1.259 & .635 & -.219 & -1.984 & .051 \\
\hline
\end{tabular}

\section{Pengujian Hipotesis Delapan}

Variabel Tingkat Kepatuhan Mandatory Disclosure (MD) Konvergensi IFRS memiliki tingkat signifikansi sebesar $0,051>$ alpha $(0,05)$ dengan nilai koefisien regresi sebesar -1.259. Dengan demikian hipotesis delapan $\left(\mathrm{H}_{8}\right)$ ditolak. Tidak terdukungnya hipotesis kedelapan diduga karena adanya faktor lain yang mempengaruhi keputusan investasi seorang investor. Beberapa hal yang biasanya dijadikan investor sebagai dasar pengambilan keputusan investasi antara lain : informasi terkait kinerja perusahaan yang tercermin pada laba yang diperoleh perusahaan, besar dividen yang akan diterima serta rencana jangka panjang terkait dengan proyek-proyek yang akan dilaksanakan perusahaan di masa depan. Hasil penelitian ini sejalan dengan penelitian yang dilakukan Ahmad, dkk. (2017).

\section{KETERBATASAN PENELITIAN}

Keterbatasan dalam penelitian ini adalah penelitian hanya terbatas pada perusahaan BUMN yang terdaftar di Bursa Efek Indonesia saja, sehingga belum memberikan informasi secara luas tentang mandatory disclosure. Hanya menggunakan tujuh proksi mekanisme corporate governance, sedangkan masih terdapat banyak proksi lain yang tidak diteliti dalam penelitian ini. Tujuh proksi mekanisme corporate governance yang digunakan dalam penelitian ini adalah kepemilikan manajerial, kepemilikan institusional, kepemilikan asing, jumlah anggota dewan komisaris, proporsi komisaris independen, jumlah rapat dewan komisaris dan jumlah anggota komite audit. Hasil uji $\mathrm{F}$ pada model penelitian kedua memiliki nilai signifikan $0,051>$ alpha $(0,05)$. Hal tersebut mengindikasikan bahwa model penelitian kedua belum memenuhi asumsi kelayakan model atau fitness model pada alpha 0,05 atau 5\%. Return saham dipengaruhi oleh banyak faktor, namun pada 
penelitian ini tidak terdapat variabel kontrol sehingga tingkat kepatuhan mandatory disclosure konvergensi IFRS tidak mempengaruhi return saham.

\section{KESIMPULAN}

Berdasarkan analisis dan pengujian data dalam penelitian ini, dapat ditarik kesimpulan kepemilikan manajerial tidak berpengaruh positif terhadap tingkat kepatuhan mandatory disclosure konvergensi IFRS. Kepemilikan institusional tidak berpengaruh positif terhadap tingkat kepatuhan mandatory disclosure konvergensi IFRS. Kepemilikan asing berpengaruh positif terhadap tingkat kepatuhan mandatory disclosure konvergensi IFRS. Jumlah anggota dewan komisaris berpengaruh positif terhadap tingkat kepatuhan mandatory disclosure konvergensi IFRS. Proporsi Komisaris Independen tidak berpengaruh positif terhadap tingkat kepatuhan mandatory disclosure konvergensi IFRS. Jumlah rapat dewan komisaris berpengaruh positif terhadap tingkat kepatuhan mandatory disclosure konvergensi IFRS. Jumlah anggota komite audit berpengaruh positif terhadap tingkat kepatuhan mandatory disclosure konvergensi IFRS. Tingkat kepatuhan mandatory disclosure konvergensi IFRS tidak berpengaruh positif terhadap return saham.

Berdasarkan hasil penelitian ini terdapat beberapa saran untuk perbaikan penelitian kedepanya, saran tersebut menambahkan proksi mekanisme corporate governance pada model penelitian pertama, seperti dualitas peran dewan komisaris atau dualitas peran CEO. Return saham dapat dipengaruhi oleh beberapa faktor, oleh karena itu pada penelitian selanjutnya disarankan untuk menambahkan variable kontrol, seperti leverage, size dan profitabilitas. Dengan ditambahkannya variable kontrol, diharapkan mampu mengendalikan pengaruh variabel independen terhadap variabel dependen dari faktor lain yang tidak diteliti. Pada penelitian ini, peneliti hanya menganalisis pengungkapan wajib pada laporan laba rugi komprehensif, diharapkan untuk penelitian berikutnya dapat melakukan analisis pengungkapan wajib laporan keuangan secara menyeluruh. Perusahaan BUMN yang digunakan sebagai objek penelitian ini belum mampu memberikan informasi secara luas tentang mandatory disclosure, sehingga untuk penelitian selanjutnya diharapkan menggunakan objek perusahaan yang berbeda, misalnya perusahaan nonkeuangan. Ditambahkan variabel Konvergensi IFRS untuk mengontrol tahapan konvergensi IFRS di Indonesia.

\section{DAFTAR PUSTAKA}

Absari, Dyatri Utami Arian, dkk. (2013). Analisis Pengaruh Faktor Fundamental Perusahaan dan Risiko Sistematis terhadap Return Saham. Jurnal Manajemen dan Akuntansi Terapan, 3, (1). Ahmad, Imam Baihaqi, dkk. (2017). Dampak Tingkat Pengungkapan Informasi Perusahaan terhadap Aktivitas Volume Perdagangan dan Return Saham (Studi Empiris Terhadap Perusahaan Manufaktur Yang Terdaftar Di Bursa Efek Indonesia Periode 2013-2015). eJurnal Ilmiah Riset Akuntansi 6.

Alvionita, I., \& Taqwa, S. (2015). Pengaruh Struktur Kepemilikan dan Mekanisme Corporate Governance Terhadap Tingkat Kepatuhan Mandatory Disclosure. Seminar Nasional Ekonomi Manajemen dan Akuntnasi (SNEMA) Fakuktas Ekonomi, Universitas Negeri Padang.

Budi, T. S. W., \& Djazuli, A. (2012). Pengaruh Pengungkapan Corporate Social Responsibility dan Kinerja Keuangan Perusahaan terhadap Return Saham Perusahaan di Indeks LQ45 Bursa Efek Indonesia Periode 2008-2010. Jurnal Ilmiah Mahasiswa FEB Universitas Brawijaya Vol 1 No.2.

Environmental Disclosure terhadap Return Saham. EProceedings of Management Telkom University Vol 1 No.3.

Fatin, N. N. (2017). Pengaruh Struktur Corporate Governance terhadap Pengungkapan Wajib Konvergensi IFRS pada Laporan Laba Rugi Komprehensif. Buletin Ekonomi, 15(1). 
Fauziah, I. (2015). Pengaruh Mekanisme Corporate Governance terhadap Tingkat Kepatuhan Mandatory Disclosure Pasca Konvergensi IFRS. Esensi Jurnal Bisnis dan Manajemen, 5, 2.

Gunawan, B., \& Hendrawati, E. R. (2016). Peran Struktur Corporate Good Governance dalam Tingkat Kepatuhan Pengungkapan Wajib Periode Setelah Konvergensi IFRS. Berkala Akuntansi dan Keuangan Indonesia, 1(1).

Hafiz, Rizki M, dkk. (2015). Pengaruh Struktur Corporate Governance terhadap Tingkat Kepatuhan Pengungkapan Wajib Konvergensi IFRS pada Laporan Laba Rugi Komprehensif (Studi pada Perusahaan Perbankan yang Listing di Bursa Efek Indonesia Tahun 2012-2013). Simposium Nasional Akuntansi 18, Medan.

Hikmah, Noor, dkk. (2011). Faktor - faktor yang Mempengaruhi Luas Pengungkapan Corporate Governance dalam Laporan Tahunan Perusahaan Perbankan yang Terdaftar di Bursa Efek Indonesia. Simposium Nasional Akuntansi XIV,Aceh.

Istiningrum, Andian Ari. (2016). Karakteristik Perusahaan sebagai Anteseden Pengungkapan Wajib Informasi Akuntansi. Jurnal Economia Vol 12 No.1.

Kaihatu, Thomas S. (2006). Good Corporate Governance dan Penerapannya di Indonesia. Jurnal Manajemen dan Kewirausahaan Vol 8 No.1.

Kharis, Abdul \& Suhardjanto, Djoko. (2012). Corporate Governance dan Ketaatan Pengungkapan Wajib pada Badan Usaha Milik Negara. Jurnal Keuangan dan Perbankan Vol.16 No.1.

Linda, Wulan Mey \& Kurnia. (2017). Pengaruh Profitabilitas, Ukuran Perusahaan dan Struktur Kepemilikan terhadap Nilai Perusahaan. Jurnal Ilmu dan Riset Akuntansi Vol 6 No.12.

Marunung, M. (2006). Investasi Asing, Antara Mitos dan Realita. Warta Ekonomi. Jakarta.

Meiflowerina, dkk. (2014). Peran Corporate Governance terhadap Tingkat Kepatuhan Mandatory Disclosure Konvergensi IFRS pada Badan Usaha Milik Negara (BUMN) yang Terdaftar di Bursa Efek Indonesia (BEI). e-Jurnal Universitas Bung Hatta Vol. 4, No. 1.

Muntoro, R.K. (2006). Membangun Dewan Komisaris yang Efektif. Makalah.

Naratama, Reza P. \& Majidah. (2014). Pengaruh Environmental Performance dan

Nastiti, Anggraini Dwi \& Ratmono, Dwi. (2015). Analisis Pengaruh Konvergensi IFRS terhadap Manajemen Laba dengan Corporate Governance sebagai Variabel Moderating. Diponegoro Journal of Accounting Vol 4 No.3.

Nazaruddin, Ietje \& Basuki, Agus T. 2017. Analisis Statistik dengan SPSS. .Sleman : Denisa Media

Pitasari, A., \& Septiani, A. (2014). Analisis Pengaruh Struktur Corporate Governance Terhadap Tingkat Kepatuhan Pengungkapan Konvergensi IFRS Pada Laporan Laba Rugi Komprehensif. (Doctoral Dissertation, Fakultas Ekonomika Dan Bisnis).

Prawinandi, W., Suhardjanto, D., \& Triatmoko, H. (2012). Peran Struktur Corporate Governance Dalam Tingkat Kepatuhan Mandatory Disclosure Konvergensi IFRS. Simposium Nasional Akuntansi $X_{V}$, Banjarmasin.

Rahayuni, Nastiti, dkk. (2018). Mampukah Kinerja Keuangan Memediasi Pengaruh Mekanisme Corporate Governance terhadap Pengungkapan Modal Intelektual?. Jurnal Kä̈an Akuntansi Vol 2 No.1.

Ramadhani. (2016). Pengaruh Stuktur Corporate Governance terhadap Tingkat Kepatuhan Mandatory Disclosure di Indonesia. Skripsi.

Rustiarini, Ni Wayan. (2011). Pengaruh Struktur Kepemilikan Saham pada Pengungkapan Corporate Social Responsibility. Jurnal Ilmiah Akuntansi dan Bisnis Vol 6 No.1.

Sugiyanto, Eviatiwi Kusumaningtyas. (2011). Peningkatan Return Saham dan Kinerja Keuangan melalui Corporate Social Responsibility dan Good Corporate Governance. Jurnal Ilmu Ekonomi ASET Vol 13 No.1.

Suhardjanto, Djoko \& Miranti, Laras. (2009). Indonesian Environmental Reporting Index dan Karakteristik Perusahaan. Jurnal Akuntansi dan Auditing Indonesia Vol 13 No.1. 
Suhardjanto, Djoko \& Yulianingtyas, Rena Rukmita. (2011). Pengaruh Karakteristik Pemerintah Daerah terhadap Kepatuhan Pengungkapan Wajib dalam Laporan Keuangan Pemerintah Daerah (Studi Empiris pada Kabupaten/Kota di Indonesia). Jurnal Akuntansi dan Auditing Vol 8 No.1.

Sunardi, Harjono. (2010). Pengaruh Penilaian Kinerja dengan ROI dan EVA terhadap Return Saham pada Perusahaan yang Tergabung dalam Indeks LQ 45 di Bursa Efek Indonesia. Jurnal Akuntansi Vol.2 No.1: 70-92.

Sutiyok, S., \& Rahmawati, E. (2016). Pengaruh Mekanisme Corporate Governance Terhadap Tingkat Kepatuhan Mandatory Disclosure Konvergensi IFRS di Perbankan. Jurnal Akuntansi Dan Investasi Vol 15 No.2, 151-162.

Utami, Wulan Dwi, dkk. (2012). Investigasi dalam Konvergensi IFRS di Indonesia: Tingkat Kepatuhan Pengungkapan Wajib dan Kaitannya dengan Mekanisme Corporate Governance. Simposium Nasional Akuntansi 15, Banjarmasin.

Vanica, Serly. (2017). Pengaruh Tata Kelola Perusahaan dan Struktur Kepemilikan terhadap Jumlah Pengungkapan PSAK Berbasis IFRS. Economac Vol 1 Issue 1.

Widjayanti, Septri Ari \& Wahidawati. (2015). Pengaruh Struktur Dan Mekanisme Corporate Governance pada Tingkat Kepatuhan Mandatory Disclosure Konvergensi IFRS. Jurnal IImu \& Riset Akuntansi Vol 4 No.7.

Yuliana, Rahmi Dwi. (2016). Pengaruh IFRS Convergence, Corporate Governance, dan Ownership Structure terhadap Tingkat Kepatuhan Mandatory Disclosure. Skripsi 